\title{
November 9, 1915.
}

Dr. S. F. Harmer, M.A., F.R.S., Vice-President, in the Chair.

The Secretary read the following report on the Additions to the Society's Menagerie during the month of October 1915 :-

The number of registered additions to the Society's Menagerie during the month of October was 162. Of these 98 were acquired by presentation, 24 were received on deposit, 15 in exchange, 11 by purchase, and 14 were born in the Gardens.

The number of departures during the same period, by death and removals, was 206.

Amongst the additions special attention may be directed to:-

1 Hairy Tree-Porcupine (Coendu insidiosus), from Venezuela, presented by Hugo Pam, C.M.Z.S., on October 4th.

2 Larger-streaked Spider-hunters (Arachnothera magna), from the Himalayas, new to the Collection, presented by Alfred Ezra, F.Z.S., on October 1st.

1 Red-faced Crake (Neocrex erythrops), new to the Collection, presented, with a number of other birds from Venezuela, by Hugo Pam, C.M.Z.S., on October 4th.

1 Japanese Robin (Erithacus akahige), from Japan, and 1 Yellow-collared Ixulus (Ixulus flavicollis), from the Himalayas, both new to the Collection, deposited on October 13th.

1 Greater Amethyst Sunbird (Chalcomitra amethystina), from South Africa, new to the Collection, presented by Alfred Ezra, F.Z.S., on October 20th.

1 Sauvage's Tree-Frog (Phyllomedusa sauvagii), from Cordova, Argentina, new to the Collection, presented by Wilfred A. Smithers, C.M.Z.S., on October 20th.

Prof. H. Maxweld Lefroy, M.A., F.Z.S., Curator of Insects, read a report on the House-Fly Investigations carried out during the present year in the Society's Gardens.

It is hoped that this report will be published in full in the 'Proceedings' for 1916.

\section{Notes from the Caird Insect House.}

Mr. C. J. C. Pool, Assistant Curator of Insects, read the following notes upon species recently bred and exhibited:-

\section{ORTHOPTERA.}

M A N T I D A.

Sphodromantis guttata.

The female Mantid deposits her eggs in a case made of a gummy secretion. The eggs are in regular rows inside the case, which is attached to a twig or to the bark of a tree. There is an 
opening along the centre of the outer surface, each ego-cell being protected by a flap or door. The young emerge in a cluster and on reaching the exterior they remain suspended by threads or tubes for from 3 to 5 days. During this period they are incapable of seizing other insects or of feeding in the ordinary way, and yet they obtain sufficient nourishment to increase their size very considerably within a week. I have observed this development upon several occasions, and it is my opinion that we must regard the egg-case as a kind of feeding-bottle capable of supplying the young Mantids with liquid food, absorbed through the threads or tubes by which they are suspended until the first moult. After this important event they are active and are at last capable of an independent existence. To test my "feedingbottle" theory I have on several occasions severed the connection between the young larva and the egg-case. The result was the same every time, and the creature died without further development.

I have examined several cases from which the young had emerged, and found that they all contained fluid matter which might form the necessary food, probably with the assistance of rain or dew.

The specimen referred to in a previous paper (P.Z.S. 1915, p. 289) lived from 6th July, 1914, until 24th September, 1915. On 19th August, 1915, it fractured a front leg, a mishap which reduced its chances of seizing a meal. Upon the third day following the accident, the Mantid surprised me by devouring the offending and still unsevered limb, after which it appeared to revive its interest in life by depositing an egg-mass, the eighth in its lifetime in the Society's Gardens. It died shortly after this event, having completed nearly fifteen months of active life.

\section{Sphodromantis gastrica.}

An eg-mass from Pretoria produced some young Mantids on 28th May, 1915. The majority of these died in the earlier stages. One fine female specimen, having devoured a number of her own kind and an abundance of other insect-food, arrived at maturity and developed her wings on October 18th, 1915, having occupied nearly five months in the process. This specimen is still alive and healthy, her food consisting principally of stick-insects. A few egg-masses produced numerous small Parasitic Hymenoptera (Chalcids) new to science, which when described will form the subject of another paper.

\section{Coleoptera.}

DER M E T T D \&.

\section{Thaumaglossa bimaculata Arrow.}

Some Mantid egg-masses received from Pretoria in May 1915 were found to be inhabited by Coleopterous larve much resembling 
the museum pest Anthrenus musearum. The infested cases were isolated and kept under observation. The larvæ fed upon the contents of the egg-masses, and duly pupated within their own skins. The beetles have been emerging during September and October.

The genus Thaumaglossa is represented in the National Collection by eight species known to inhabit egg-masses of Mantids, their distribution being China, S. Australia, Nigeria, Rhodesia, and the Malay Peninsula. The insect now exhibited was examined by Mr. G. J. Arrow at the British Museum (Nat. Hist.) and has been described by him under the above name.

The type-specimen will be deposited in the National Collection and the co-type in the general reference collection now in course of formation in the Caird Insect House.

\section{PTINID}

Ptinus pusillus Sturm.

This active little beetle is a well-known granary pest in France and Germany, but was not known to inhabit this country until 1906, when I discovered it in a corn-shop at Edmonton.

The female, which is more robust than the male and with shorter antennæ, has for some years been confounded with another species, P. testacens Boield., in British works and collections.

I have taken both sexes in profusion in the Society's Gardens, and it is due to the study of the specimens collected there and at Edmonton that I have been able to clear up this old error.

\section{Ptinus tectus Boield.}

This beetle is another cosmopolitan granary pest, and during the last few years has become exceedingly common throughout this country. During last May a so-called insect-destroyer was recommended and submitted for test upon some Blow-fly maggots. It was not a success, its intended victims proving its ineffectiveness by simply pupating in a dish of the supposed deadly powder. The paper-bag containing the remainder was put aside in a cupboard in the Fly-room, and was forgotten until after the closing of the Fly Exhibition in September, when upon clearing out an accumulation of samples, etc., I noticed numerous small round perforations in the bag which had become slightly mouldy, and, upon peeling back the paper near the perforations, I discovered $P$. tectus, larvæ, pupæ, and imagos, perfectly healthy and apparently enjoying the novelty of breeding in an insect-killing powder, which actually appears to be a vegetable-meal upon which a corn-shop pest might be expected to thrive.

In conclusion, I must confess to a feeling of pleasure in recording the successful rearing of an African beetle new to 
science in the Caird Insect House, as well as the correction of an error which has caused considerable confusion in connection with the species of Ptimus. We have been handicapped by reduction of staff, our two helpers having joined the colours, otherwise we might have accomplished some other useful research-work with the aid of valuable living material received from various sources. Some day, under happier circumstances, we hope to be able to devote more attention to breeding, etc., thereby adding to the scientific value as well as to the popular interest of the Caird Insect House.

\section{November 23, 1915.}

Dr. A. Sмiтh Woodward, F.R.S., Vice-President, in the Chair.

Mr. R. W. Harold Row, B.Sc., F.Z.S., exhibited photographs of an interesting abnormal Frog (Rana temporaria), in which both posterior limbs lacked the hallux, though the calcar, or prehallux, was present on each side. The characteristic structure of the digits still existing clearly proved that the missing toe was the hallux, and dissection showed that there was no trace of it internally. All the other four digits were perfectly normal.

A complete description of this abnormality, with illustrations, will be published in the next part of the 'Proceedings.' 


\section{$2 \mathrm{BHL}$ Biodiversity Heritage Library}

Harmer, S. F. 1915. "November 9, 1915." Proceedings of the Zoological Society of London 1915, 709-712. https://doi.org/10.1111/j.1469-7998.1915.00709.x.

View This Item Online: $\underline{\text { https://www.biodiversitylibrary.org/item/98466 }}$

DOI: https://doi.org/10.1111/j.1469-7998.1915.00709.x

Permalink: https://www.biodiversitylibrary.org/partpdf/72195

\section{Holding Institution}

Smithsonian Libraries

\section{Sponsored by}

Biodiversity Heritage Library

\section{Copyright \& Reuse}

Copyright Status: Public domain. The BHL considers that this work is no longer under copyright protection.

This document was created from content at the Biodiversity Heritage Library, the world's largest open access digital library for biodiversity literature and archives. Visit BHL at https://www.biodiversitylibrary.org. 